\title{
Fatty acid and proteomic analysis of Sterculia striata nut
}

\author{
Míriam Andrade SANTOS ${ }^{1}$, Ederson Paulo Xavier GUILHERME ${ }^{1}$, Lorendane Millena CARVALHO ${ }^{2}$, \\ Igor Viana BRANDI ${ }^{1}$, Gleidson Giordano Pinto CARVALHO ${ }^{3}$, Junio COTA ${ }^{1}$, \\ Bruna Mara Aparecida de CARVALHO ${ }^{1 *}$ (iD
}

\begin{abstract}
Chicha (Sterculia striata) is a native plant of the Cerrado biome that has only recently been explored nutritionally. The aim of this study was to determine its fatty acid profile and obtain the proteomic analysis of chicha nut. The nut was found to be composed of $22.19 \%$ protein, $20.62 \%$ lipids, 3.91\% moisture, 3.63\% ash, 53.56\% carbohydrates, $19.99 \%$ neutral detergent fiber and $3.99 \%$ acid detergent fiber. With regard to fatty acids; 5 components were identified, of which $56.2 \%$ were unsaturated fatty acids. Oleic acid presented the highest fatty acid content in chicha, followed by palmitic acid. With regard to the nut's protein content; 2 proteins were identified, legumin, a soluble globulin, and prurin-1, the most allergic component of $11 \mathrm{~S}$ globulins. The identification of the characteristics of chicha provides nutritional and functional information regarding this plant and its contribution to food products.
\end{abstract}

Keywords: chicha; proteins; maldi-tof; cerrado; mass spectrometry.

Practical Application: The study demonstrates the richness of fruits that are part of the Cerrado population.

\section{Introduction}

The Cerrado occupies $23 \%$ of Brazil's territory and is considered to be the second largest biome in the country. The biome is encountered in the states of Bahia, Goiás, Maranhão, Mato Grosso, Mato Grosso do Sul, Minas Gerais, Pará, Piauí, Rondônia, Tocantins and the Federal District, representing an approximate area of 2 million $\mathrm{km}^{2}$ (Stefanes et al., 2018). The Cerrado's flora boasts a variety of edible fruits, which are consumed or are used as raw material for the preparation of foods (Geocze et al., 2013).

Chicha (Sterculia striata) is a native plant of the Cerrado and pertains to the Sterculiaceae Family. This tree and its fruit are also known as xixá, amendoim-de-macaco, castanha-de-macaco, mendubi-guaçu, castanheiro-do-mato, aracha-chá and pau-rei. The plant's wood is used for crafts, ornaments, boxes and the production of matches. As the plant can tolerant dry soils and grows rapidly, it can be used to recompose degraded areas (de Britto Policarpi et al., 2018). The extract obtained from the stem of S. striata chicha is considered to be a source of bioactive compounds, which in appropriate concentrations may help in the prevention of diseases, due to their antioxidant properties (de Britto Policarpi et al., 2018). The fruit of chicha contains between 9 to 20 nut and matures during the period from June to September. Chicha nut are ovoid, $2 \mathrm{~cm}$ long, have two shells, a thin outer shell that is easy to remove, and an internal shell that is stiffer, and a nut, which can be consumed raw, cooked, toasted or as paçoca, a Brazilian dish (Silva \& Fernandes, 2011).
The protein content of chicha varies according to the region of its cultivation. In the present study, the water content of the soil was higher than that previously observed for other regions (Rocha et al., 2013; Diniz et al., 2008). Fruits from different regions may present different centesimal compositions, due to differences in soil characteristics, fertilization, climate and other environmental factors (Silva \& Fernandes, 2011).

As compared to other fruits from the Cerrado, chicha presents a higher content of follicles, and a higher content of lycopene, a bioactive antioxidant, in the alcoholic extract (Rocha et al., 2013). In addition, this fruit presents a high concentration of fibers, proteins, phosphorus, manganese and copper, the latter being an important nutrient for pregnant women (Rocha et al., 2013). According to Rocha et al. (2013), chicha presents a higher ascorbic acid (vitamin C) content than most citrus fruits, such as the poncero tangerine, the murcote tangerine, pear orange, lime orange, natal orange, Valencia orange, and bay orange.

Chicha is not very susceptible to enzymatic browning, and is reported to be a source of monounsaturated fatty acids, particularly oleic acid, with a higher content of oleic acid than those of sunflower and peanut oil (Silva \& Fernandes, 2011). In addition, chicha contains some amino acids that are important for children of 2 to 12 years of age and may be considered an alternative source of essential amino acids such as valine, isoleucine, leucine, lysine, threonine, methionine, tryptophan and cysteine (Association of Official Analytical Chemists, 1995). 
Despite knowing the amino acid composition of chicha, little is known about its protein content; as such, the main objective of this study was to obtain the proteomic analysis of chicha nut grown in the northern region of Minas Gerais, as well as its centesimal composition and fatty acid profile.

\section{Materials and methods}

\subsection{Materials}

The nut of mature fruits of chicha (Sterculia striata A.St.-Hil. \& Naudin) were collected in the northern region of the state of Minas Gerais. The nut selected were stored at $-20{ }^{\circ} \mathrm{C}$ until use, at which time they were ground in an industrial blender (Tron Master Copo Aço Inox), before sieving through a $1.68-\mathrm{mm}$ aperture sieve to obtain a homogeneous grain size. Acetic acid, formic acid, trifluoroacetic acid, ammonium bicarbonate, 1,4-Dithiothreitol (DTT), iodoacetamide, proteomic grade trypsin, hexane, sodium dodecyl sulfate (SDS), bromophenol blue, glycerol, Tris, glycine, (N-N, N-N-Tetramethylethylenediamine (TEMED), N-N-tetramethylethylenediamine hydrochloride, sodium hydroxide, potassium hydroxide, hydrochloric acid, dichloromethane, anhydrous sodium sulfate, glacial acetic acid, glacial acetic acid, acrylamide, bisacrylamide, ammonium persulfate, Sigma-Aldrich brand, GE Healthcare LMW protein standard and $\alpha$-cyano-4-hydroxycinnamic acid-HCCA were purchased from Bruker Daltonics, Germany. All solvents and reagents used were of high analytical grade.

\subsection{Nutritional properties}

Moisture content, minerals, crude protein and lipids were determined according to the methodology described by the Association of Official Analytical Chemists (1995). The contents of neutral detergent fiber (NDF) and acid detergent fiber (FDA) were obtained according to the methodology described by Sniffen et al. (1992). Total carbohydrates (TC) were estimated according to Sniffen et al., 1992, as: CT = $100-(\% \mathrm{~PB}+\% \mathrm{EE}+\% \mathrm{MM})$.

\subsection{Oil and fatty acid profile characterization}

The extraction of chicha seed oil was carried out using an automated Soxtec extractor, based on the Soxhlet direct extraction methodology reported by the Association of Official Analytical Chemists (1995).

\subsection{Chemical interesterification}

Twenty mg of sample were added to a round bottom flask $(50 \mathrm{~mL})$, followed by $5 \mathrm{~mL} \mathrm{KOH}$ solution in methanol $\left(0.5 \mathrm{~mol} \mathrm{~L}^{-1}, \mathrm{~m} / \mathrm{v}\right)$. The mixture was heated to $100{ }^{\circ} \mathrm{C}$ for $1 \mathrm{~h}$ under reflux. For the esterification, $2 \mathrm{~mL}$ of $\mathrm{HCl}$ solution in methanol $(4: 1, \mathrm{v} / \mathrm{v})$ were added to the mixture and heated again at $100{ }^{\circ} \mathrm{C}$ for $1 \mathrm{~h}$. The methyl esters were extracted and, after cooling, $2.0 \mathrm{~mL}$ of distilled $\mathrm{H}_{2} \mathrm{O}$ was added; the derivatives obtained were then extracted with dichloromethane $(3 \times 5.0 \mathrm{~mL})$. After extraction, the organic phase was dried with anhydrous sodium sulfate, filtered and concentrated. The residue obtained, after complete removal of the solvent, was dissolved in $1 \mathrm{~mL}$ of dichloromethane and analyzed by GC-MS.

\subsection{Chromatographic conditions}

Chromatographic analyzes were performed on a gas chromatograph (Agilent Technologies, GC 7890A) equipped with a mass detector (CG-EM) and DB-5MS capillary column (Agilent Technologies, $30 \mathrm{~m}$ length $\mathrm{x} 0.25 \mathrm{~mm}$ internal diameter x $0.25 \mu \mathrm{m}$ film thickness). Helium (99.99\% purity) was used as the entrainment gas at a rate of $1 \mathrm{~mL} \mathrm{~min}{ }^{-1}$. Using a self-injector (CTC combiPaL), $1 \mu \mathrm{L}$ of the sample was injected into the chromatograph at a 1:10 split ratio. The split/splitless injector was maintained at $220^{\circ} \mathrm{C}$. The chromatographic column was maintained initially at $160{ }^{\circ} \mathrm{C}$ for $2 \mathrm{~min}$, and heated at a rate of $2{ }^{\circ} \mathrm{C} \mathrm{min}^{-1}$ to $200^{\circ} \mathrm{C}$ and then up to $240{ }^{\circ} \mathrm{C}$ at a rate of $10^{\circ} \mathrm{C}$ $\mathrm{min}^{-1}$. After separation of the compounds, the temperature was raised to $300{ }^{\circ} \mathrm{C}$ for 3 minutes (post run). The interface temperature was maintained at $240{ }^{\circ} \mathrm{C}$ and the ionization was performed with $70 \mathrm{eV}$ impact. The scanning range of $\mathrm{m} / \mathrm{z}$ was from 30 to $600 \mathrm{Da}$.

\subsection{Electrophoretic profile characterization by SDS-PAGE}

A sample of $0.1 \mathrm{~g}$ of dried and processed chicha was subjected to protein extraction by the addition of $1 \mathrm{~mL}$ of SDS-sample buffer (0.125M Tris-HCl, $20 \%$ glycerol, $10 \%$ SDS, $0.02 \%$ bromophenol blue, $0.2 \mathrm{M} \mathrm{DTT}$ ). The sample was centrifuged at $10,500 \mathrm{rpm}$ for $10 \mathrm{~min}$, and the soluble proteins were denatured by heating the sample over a period of $5 \mathrm{~min}$. Aliquots of $10 \mu \mathrm{L}$ of each sample of soluble proteins were submitted to SDS-PAGE electrophoresis in gels of $1 \mathrm{~mm}$ thickness ( $3 \mathrm{~cm}$ and $6.5 \mathrm{~cm}$ of $4 \%$ stacking, $15 \%$ gel resolution) as described by Laemmli (1970). Gels were run at $100 \mathrm{~V}$ over a period of 3 and a half hours. Afterwards, the gel was stained with coomassie blue solution $(0.01 \% \mathrm{w} / \mathrm{v})$ and decolorized with methanol, acetic acid and water solutions, 450: 100: $450(\mathrm{v} / \mathrm{v})$, until complete revelation of the bands. The gel was stored in $5 \%$ acetic acid solution at room temperature until MALDI-TOF proteomic identification.

\subsection{Separation and Identification of proteins by Mass Spectrometry (MALDI-TOF)}

\section{Enzymatic digestion of bands on the gel}

Enzyme digestion was performed with TPCK-treated swine pancrease trypsin. Protein digests were performed as previously described by Shevchenko et al. (2007) with a trypsin concentration of $25 \mathrm{ng} / \mu \mathrm{L}$. After digestion, the tryptic peptides were dried in a vacuum centrifuge, model AG-22331 (Eppendorf, Germany) and stored at $-20^{\circ} \mathrm{C}$ until use.

\section{Analysis by mass spectrometry}

Tryptic peptides from all samples were resuspended in $10 \mu \mathrm{L}$ of $50 \%$ acetonitrile solution, acidified with $0.1 \%$ trifluoroacetic acid. The matrix used was $\alpha$-cyano-4-hydroxycinnamic acid-HCCA, solubilized in the same solution from which the tryptic peptides were resuspended, to a final concentration of $10 \mathrm{mgmL}^{-1}$. Standard peptides were used for calibration of the MS1 analysis method. Then, $1 \mu \mathrm{L}$ of sample and $1 \mu \mathrm{L}$ of matrix were applied and homogenized in each spot of a steel plate suitable for analysis. The spectra of MS1 and MS2 were acquired in the 
MALDI-TOF/TOF spectrometer (Ultraflex III model, Bruker Daltonics). For MS1 data, the reflective and positive mode was used, with a detection range of 500-3400 Da. MS2 data was obtained using the LIFT method in the positive mode, for which the ions with the highest intensity in relation to the mass ratio $(\mathrm{m} / \mathrm{z})$ were selected. All the data obtained were managed by the Flexcontrol software, version 3.3 (Bruker Daltonics, Germany), and the spectra resulting from the MS1 and MS2 analyzes were processed using the flexAnalysis application, version 3.3 (Bruker Daltonics, Germany). Peak lists of MS2 were generated in the mascot generic format (mgf) format by the BioTools application, version 3.2 (Bruker Daltonics, Germany).

\section{Identification of proteins}

The mass lists were compared to the databases of proteins of the Malvaceae family species, deposited in UNIPROT, and the group of green plants (Viridiplantae), also deposited in UNIPROT. The MASCOT software, version 2.4.0 (Matrix Science, London, UK) was used for this comparison, using the following parameters: enzymatic digestion by trypsin with a lost cleavage; allowing a tolerance of error for the parental ion of $0.2 \mathrm{Da}$ and for the fragments of $0.5 \mathrm{Da}$; carbamidomethylation of cysteine as a fixed modification and oxidation of methionine as a variable modification. The result obtained by MASCOT was validated by the application SCAFFOLD, version 3.6.4 (Proteome Software INc., Portland, OR). For the validation of the peptides identified, the Peptide Prophet algorithm was applied (Keller et al., 2002) and the Protein Prophet algorithm (Nesvizhskii et al., 2003) was used as the acceptance criteria, with parameters of at least $90 \%$ probability of identification for both peptides and proteins, with the presence of at least one single peptide for each identified protein.

\section{Results and discussion}

\subsection{Centesimal composition}

The centesimal composition of chicha nut is presented in Table 1.

The chicha analyzed had higher protein levels $(22.19 \mathrm{~g} / 100 \mathrm{~g})$ and total carbohydrates $(53.56 \mathrm{~g} / 100 \mathrm{~g})$, when compared to chicha from other states of Brazil, which presented protein contents of 17.4 and $19.9 \mathrm{~g} / 100 \mathrm{~g}$ and carbohydrate contents of 45.1 and $40,6 \mathrm{~g} / 100 \mathrm{~g}$ for carbohydrates, respectively. The chicha analyzed also demonstrated lower concentrations of lipids $(20.62 \mathrm{~g} / 100 \mathrm{~g})$ and humidity $(3.91 \mathrm{~g} / 100 \mathrm{~g})$ than the species

Table 1. Centesimal composition of the nut of Sterculia striata.

\begin{tabular}{cc}
\hline Components & $(\mathrm{g} / 100 \mathrm{~g})$ Chicha \\
\hline Moisture & $3.91 \pm 0.05$ \\
Ashes & $3.63 \pm 0.01$ \\
TC & $53.56 \pm 0.02$ \\
Lipids & $20.62 \pm 0.02$ \\
Proteins & $22.19 \pm 0.01$ \\
NDF & $19.99 \pm 0.01$ \\
FDA & $3.99 \pm 0.01$ \\
\hline
\end{tabular}

TC $=$ Total Carbohydrates, $\mathrm{NDF}=$ Neutral Detergent Fiber, FDA $=$ Fiber in Detergent Acid. Means \pm S.D., $\mathrm{n}=3$. in other states $(28.6$ and $25.82 \mathrm{~g} / 100 \mathrm{~g}$ for lipids; $11.02 \mathrm{~g} / 100 \mathrm{~g}$ and $11.5 \mathrm{~g} / 100 \mathrm{~g}$ for moisture, respectively). According to Silva \& Fernandes (2011), fruits from different regions may present different compositions, due to differing soil characteristics, fertilization, climate and other environmental factors. The protein content found in chicha was higher than that found in other nuts commonly consumed in Brazil, such as coconuts and Brazil nuts (Universidade Estadual de Campinas, 2011). According to Jean et al. (2002), chicha is considered an important source of proteins, since over $20 \%$ of this macroelement is contained in its composition.

According to Rocha-Olivieri et al. (2012), the NDF fraction of chicha consists of cellulose, hemicellulose, lignin and lignin protein, and the FDA fraction corresponds to the less digestible portion of the cell wall and consists almost entirely of lignocellulose, i.e. cellulose and lignin. According to Cecchi (2003) the determination of dietary fiber in cereal grains is officially determined using NDF methodology. Dietary fiber is not considered an energy source because it does not undergo hydrolysis by the enzymes of the human intestine and can be fermented by some bacteria (Pimentel et al. 2005). According to Dhingra et al. (2012), chicha can be considered an excellent source of dietary fiber, since it has a higher content than the minimum established, of 3-6 $\mathrm{g}$ of fiber per $100 \mathrm{~g}$ of product.

\subsection{Characterization of fatty acids}

The analysis of the chemical composition of chicha nut oil by CG/MS allowed the observation of 6 peaks, as can be observed in Figure 1.

However, it was possible to identify 5 fatty acid constituents in chicha, according to Table 2 . Of these fatty acids, $56.2 \%$ are unsaturated fatty acids, represented by methyl (Z) -hexadec-9-enoate (palmitoleic acid), methyl (Z) -octadec-9-enoate, known as oleic acid, and (9Z, 12Z) -octadeca-9,12-dienoate (linoleic acid) (Table 2). According to Orsavova et al. (2015), unsaturated fatty acids are most commonly found in vegetable fats, which is in line with the results obtained in this study.

Linoleic acid is considered an essential fatty acid, since its synthesis is not possible in the human body. Linoleic acid is important for the regulation of hormone metabolism, including cholesterol synthesis (Kaur et al., 2012). Oleic acid is one of the most widely distributed fatty acids in nature, and is found in both animal and vegetable oils and fats (Orsavova et al., 2015). A recent study showed that oleic acid, the fatty acid with the highest content found in chicha oil, contributes to the reduction of levels of genes related to the development of breast cancer (Menendez et al., 2005).

Oleic acid and stearic acid, both found in the fixed oil of chicha, have the ability to reduce LDL (Low Density Lipoprotein) levels and elevate the levels of HDL (High Density Lipoprotein) in blood plasma, contributing to reduce the risk for heart attack (Lottenberg, 2009). Palmitic acid, the main fatty acid found in palm oil and the fatty acid with the second highest concentration in chicha oil, has low stability when subjected to high temperatures; in order to avoid the oxidation of this oil, it 


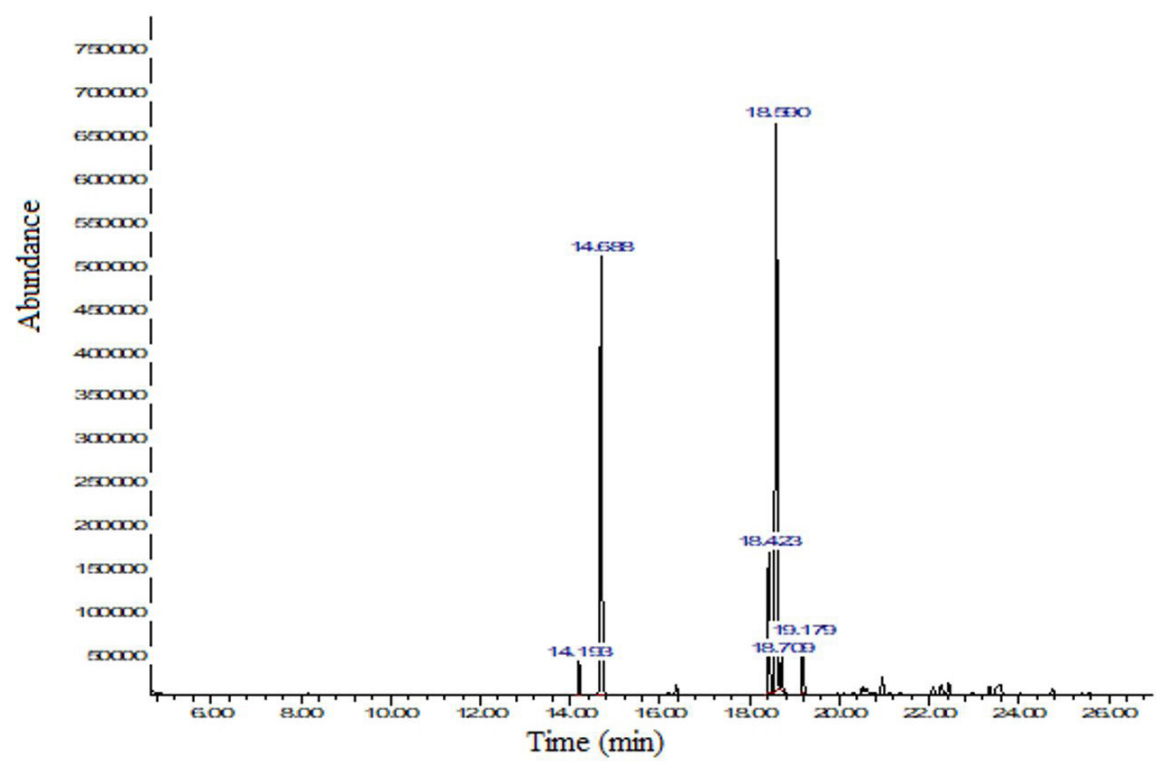

Figure 1. Chromatogram of total ions of chicha oil samples. The peak numbers refer to the holding time of each fatty acid.

Table 2. Chemical composition of chicha oil samples. RT-Retention time, NI-Not identified.

\begin{tabular}{cccc}
\hline Peak & RT & Average & Identification \\
\hline 1 & 14.193 & 1.9 & (Z) -hexadec-9-enoate (palmitoleic acid) \\
2 & 14.688 & 37.7 & Methyl hexadecanoate (palmitic acid) \\
3 & 18.423 & 6.5 & $(9 \mathrm{Z}, 12 \mathrm{Z}$ ) -octadeca-9,12-dienoate (linoleic acid) \\
4 & 18.590 & 47.8 & $(9 \mathrm{Z}, 12 \mathrm{Z})$-octadeca-9,12-dienoate (linoleic acid) \\
5 & 18.709 & 1.9 & NI \\
6 & 19.179 & 4.2 & Methyl octadecanoate (stearic acid) \\
\hline
\end{tabular}

is important to avoid its exposure to temperatures higher than $175^{\circ} \mathrm{C}$ (Chen et al., 2017).

In study conducted by Hiraoka-Yamamoto et al. (2004) found that both body mass index and serum and total cholesterol and LDL levels were significantly decreased in young Japanese women who had a diet rich in macadamia oil, this oil has a high concentration of palmitoleic acid, which was also found in chicha nut.

Researchers in several areas have demonstrated the importance of studying fatty acids, Lucena et al. (2018), studied the effect of commercial tannin and a pornunca (Manihot spp.) silage-based diet on the fatty acid profile of Saanen goats' milk; Barłowska et al. (2018) determined the fatty acid profile in goat cheese relation to the geographic region of production and Mendes et al. (2013), studied the oxidative stability of cereal bars made with fruit peels and baru nuts packaged in different types of packaging

\subsection{Separation and identification of proteins}

\section{Electrophoretic SDS protein profile of chicha}

The gel image obtained from the SDS-PAGE gel analysis of chicha proteins is presented in Figure 2.

Gel electrophoresis demonstrated the presence of a range of proteins with different molecular weights, ranging from 97 to $14 \mathrm{KDa}$. Relatively weak bands of proteins were observed between the molecular markers ranging from 97 to $45 \mathrm{KDa}$. Six bands with greater intensities were observed between molecular markers from 45 to $14 \mathrm{KDa}$;

\subsection{Identification of proteins}

It was possible to identify the peptides 1) ISTLNSFNLPILR and 2) ALPDEVLANAYQISR, which presented different mass/charge ratio values $(\mathrm{m} / \mathrm{z})$ of 1487,84 and 1659,88 , respectively (Table 3 ).

These peptides were aligned, allowing the identification of different proteins, according to the databases used. Peptides 01 and 02 were found in the sample bands 01,02 and 04 , demonstrating the possibility of having more than one protein in each sample band. It was possible to identify two proteins in this experiment, legumin A and prunin-1, both considered to be reserve proteins. The nutritional reserve proteins are formed during seed development, and comprise just a few molecular species, but constitute a high percentage of the total protein in the nut (Shewry et al., 2015; Zarkadas et al., 2007). The legumes may belong to the family of globulins, found in nuts, such as Baru nuts, Brazil nuts, and cashew nuts (Zarkadas et al., 2007). According to Millward (1998), globulins are the main reserve proteins of legumes, and are responsible for the physical and nutritional properties of the protein products of the nut, with low concentrations of sulfur amino acids and tryptophan, but a high lysine content. 
Santos et al.

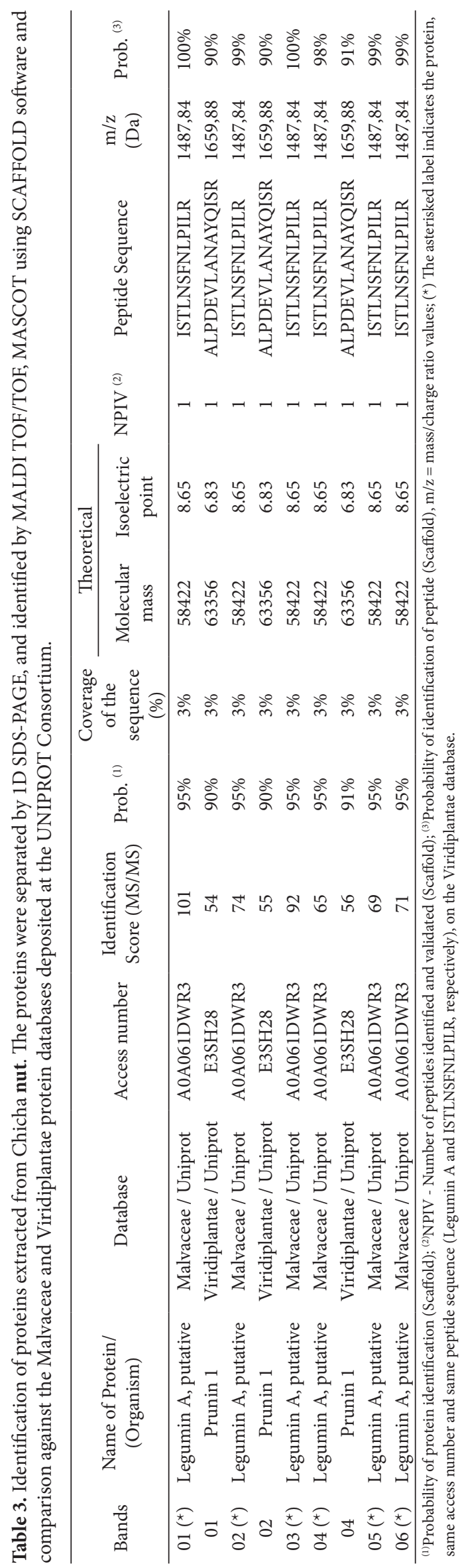


A

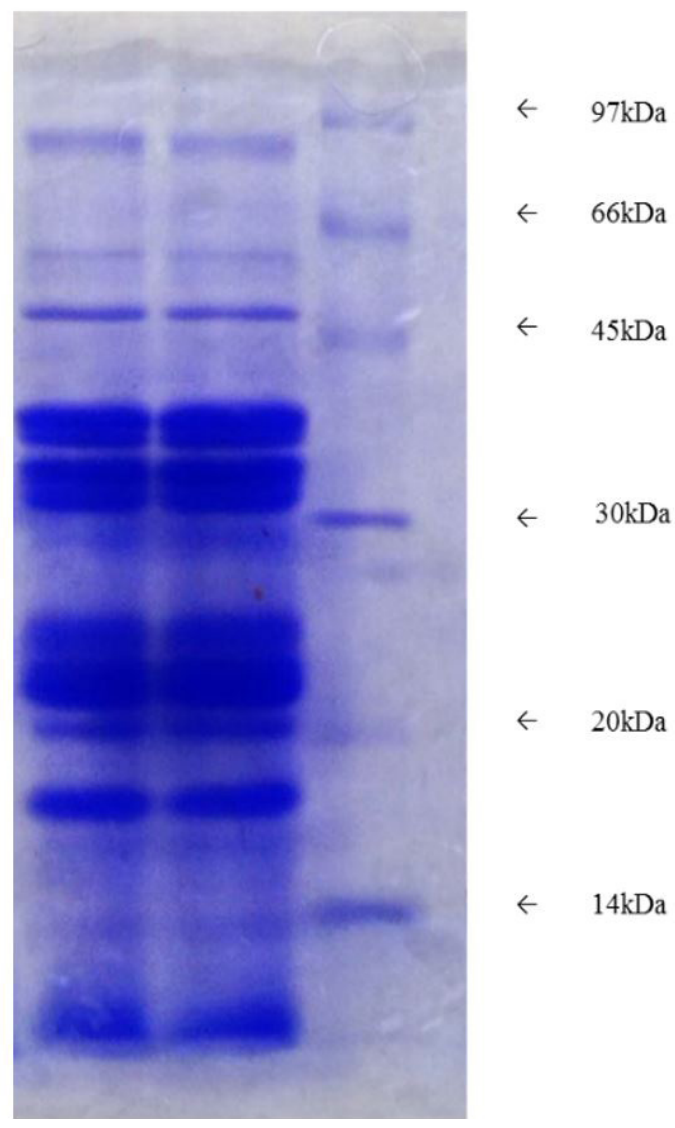

Figure 2. Electrophoretic analysis of protein extracts of chicha sample. Samples were separated on a $15 \%$ polyacrylamide gel, and stained with Comassie G-250 brilliant blue. Band P, $10 \mu \mathrm{L}$ of protein standard; bands $\mathrm{A}$ and $\mathrm{B}$ ( $10 \mu \mathrm{L}$ of chicha protein solution).

All these characteristics are important from a nutritional and functional point of view, and some proteins have the capacity to gel, conferring greater stability of emulsion and firmness, in turn influencing the characteristics of food products (Poysa et al., 2006). Globulins may trigger allergic reactions in their consumers and should be identified in order to avoid their consumption or manipulation by those allergic to these components. Prunin- 1 is a major allergenic component, originating from 11S globulins, and is found in peanuts (Prunus dulcis) and also in chicha, thus its consumption is inappropriate for people displaying sensitivity (Jin et al., 2009).

\section{Conclusion}

The moisture and lipid contents of nut from chicha, grown in the North of Minas Gerais, were lower when compared to the values found in the same plant from other regions of the country. In contrast, the plant's contents of carbohydrate and protein were higher than in chicha from other regions. Thus, chicha represents a good source of protein and an excellent source of fiber. The fixed oil from chicha presented a high concentration of oleic acid, an omega 9 fatty acid whose consumption is associated with diverse benefits for human health. In addition, Chicha oil contained a considerable concentration of palmitic acid; therefore, heating of chicha oil should be controlled in order to avoid oxidation of palmitic acid. Two proteins were identified in several samples separated by 1D SDS-PAGE, and were identified by MASCOT and validated by SCAFFOLD as legumin A and prunin-1, both considered to be reserve proteins.

\section{Acknowledgements}

The authors acknowledge the Federal University of Minas Gerais (UFMG) and funding agencies FAPEMIG, CAPES, and $\mathrm{CNPq}$ for the financial support.

\section{References}

Association of Official Analytical Chemists - AOAC. (1995). Official methods of analysis of the Association of Official Analytical Chemists (Vol. 33, pp. 10-12). Arlington: AOAC.

Barłowska, J., Pastuszka, R., Rysiak, A., Król, J., Brodziak, A., Kędzierska-Matysek, M., Wolanciuk, A., \& Litwińczuk, Z. (2018). Physicochemical and sensory properties of goat cheeses and their fatty acid profile in relation to the geographic region of production. International Journal of Dairy Technology, 71(3), 699-708. http:// dx.doi.org/10.1111/1471-0307.12506.

Cecchi, H. M. (2003). Effect of buckwheat flour on microelements and proteins theoretical and practical foundations in food analysis. Campinas: Editora da UNICAMP.

Chen, H., Wang, Y., Cao, P., \& Liu, Y. (2017). Effect of temperature on thermal oxidation of palmitic acid studied by combination of EPR spin trapping technique and SPME-GC-MS/MS. Food Chemistry, 234, 439-444. http://dx.doi.org/10.1016/j.foodchem.2017.04.135. PMid:28551258.

de Britto Policarpi, P., Turcatto, L., Demoliner, F., Ferrari, R. A., Bascuñan, V. L. A. F., Ramos, J. C., Jachmanián, I., Vitali, L., Micke, G. A., \& Block, J. M. (2018). Nutritional potential, chemical profile and antioxidant activity of Chichá (Sterculia striata) nuts and its byproducts. Food Research International, 106, 736-744. http://dx.doi. org/10.1016/j.foodres.2017.12.069. PMid:29579982.

Dhingra, D., Michael, M., Rajput, H., \& Patil, R. T. (2012). Dietary fibre in foods: a review. Journal of Food Science and Technology, 49(3), 255266. http://dx.doi.org/10.1007/s13197-011-0365-5. PMid:23729846.

Diniz, Z. N., Bora, P. S., Queiroga Neto, V., , \& Cavalheiro, J. M. O. (2008). Sterculia striata seed kernel oil: characterization and thermal stability. Grasas y Aceites, 59(2), 160-165. http://dx.doi.org/10.3989/ gya.2008.v59.i2.505.

Geocze, K. C., Barbosa, L. C. A., Fidêncio, P. H., Silvério, F. O., Lima, C. F., Barbosa, M. C. A., \& Ismail, F. M. D. (2013). Essential oils from pequi fruits from the Brazilian Cerrado ecosystem. Food Research International, 54(1), 1-8. http://dx.doi.org/10.1016/j. foodres.2013.06.005.

Hiraoka-Yamamoto, J., Ikeda, K., Negishi, H., Mori, M., Hirose, A., Sawada, S., Onobayashi, Y., Kitamori, K., Kitano, S., Tashiro, M., Miki, T., \& Yamori, Y. (2004). Serum lipid effects of a monounsaturated (palmitoleic) fatty acid-rich diet based on macadamia nuts in healthy, young japanese women. Clinical and Experimental Pharmacology \& Physiology, 31(suppl 2), S37-S38. http://dx.doi.org/10.1111/j.14401681.2004.04121.x.

Jean, C., Fromentin, G., Tomé, D., \& Larue-Achagiotis, C. (2002). Wistar rats allowed to self-select macronutrients from weaning to maturity choose a high-protein, high-lipid diet. Physiology \& Behavior, 
76(1), 65-73. http://dx.doi.org/10.1016/S0031-9384(02)00676-5. PMid:12175590.

Jin, T., Albillos, S. M., Guo, F., Howard, A., Fu, T.-J., Kothary, M. H., \& Zhang, Y.-Z. (2009). Crystal structure of Prunin-1, a major component of the almond (Prunus dulcis) allergen amandin. Journal of Agricultural and Food Chemistry, 57(18), 8643-8651. http://dx.doi. org/10.1021/jf9017355. PMid:19694440.

Kaur, N., Chugh, V., \& Gupta, A. K. (2012). Essential fatty acids as functional components of foods- a review. Journal of Food Science and Technology, 51(10), 2289-2303. http://dx.doi.org/10.1007/ s13197-012-0677-0. PMid:25328170.

Keller, A., Nesvizhskii, A. I., Kolker, E., \& Aebersold, R. (2002). Empirical statistical model to estimate the accuracy of peptide identifications made by MS/MS and database search. Analytical Chemistry, 74(20), 5383-5392. https://doi.org/10.1021/ac025747h.

Laemmli, U. K. (1970). Cleavage of structural proteins during the assembly of the head of bacteriophage T4. Nature, 227(5259), 680685. http://dx.doi.org/10.1038/227680a0. PMid:5432063.

Lottenberg, A. M. P. (2009). Importância da gordura alimentar na prevenção e no controle de distúrbios metabólicos e da doença cardiovascular. Arquivos Brasileiros de Endocrinologia \& Metabologia, 53(5), 595-607. https://doi.org/10.1590/S0004-27302009000500012.

Lucena, A. R. F., Menezes, D. R., Carvalho, D. T. Q., Matos, J. C., Antonelli, A. C., Moraes, S. A., Dias, F. S., Queiroz, M. A. Á., \& Rodrigues, R. T. S. (2018). Effect of commercial tannin and a pornunça (Manihot spp.) silage-based diet on the fatty acid profile of Saanen goats' milk. International Journal of Dairy Technology, 71(3), 613-620. http:// dx.doi.org/10.1111/1471-0307.12504.

Mendes, N. S. R., Gomes-Ruffi, C. R., Lage, M. E., Becker, F. S., Melo, A. A. M., Silva, F. A., \& Damiani, C. (2013). Oxidative stability of cereal bars made with fruit peels and baru nuts packaged in different types of packaging. Food Science and Technology, 33(4), 730-736. http://dx.doi.org/10.1590/S0101-20612013000400019.

Menendez, J. A., Vellon, L., Colomer, R., \& Lupu, R. (2005). Oleic acid, the main monounsaturated fatty acid of olive oil, suppresses Her-2/ neu (erb B-2) expression and synergistically enhances the growth inhibitory effects of trastuzumab (Herceptin e) in breast cancer cells with Her-2/neu oncogene amplification. European Society for Medical Oncology, 16(3), 359-371. https://doi.org/10.1093/annonc/mdi090.

Millward, D. J. (1998). Quality and utilization of plant proteins in human nutrition. In J. Guéguen \& Y. Popineau (Eds.), Plant proteins from european crops: food and non food applications (pp. 169-176). USA: Springer. http://dx.doi.org/10.1007/978-3-662-03720-1_29.

Nesvizhskii, A. I., Keller, A., Kolker, E., \& Aebersold, R. (2003). A statistical model for identifying proteins by tandem mass spectrometry. Analytical Chemistry, 75(17), 4646-4658. http://dx.doi.org/10.1021/ ac0341261.

Orsavova, J., Misurcova, L., Ambrozova, J., Vicha, R., \& Mlcek, J. (2015). Fatty acids composition of vegetable oils and its contribution to dietary energy intake and dependence of cardiovascular mortality on dietary intake of fatty acids. International Journal of Molecular Sciences, 16(6), 12871-12890. http://dx.doi.org/10.3390/ijms160612871. PMid:26057750.

Pimentel, C. V. M. B., Francki, V. M., \& Gollücke, A. P. B. (2005). Alimentos funcionais: introdução as principais substâncias bioativas em alimentos (Vol. 1865). São Paulo: Ed. Varela. https://doi.org/10.1016/j. bbapap.2017.07.007.

Poysa, V., Woodrow, L., \& Yu, K. (2006). Effect of soy protein subunit composition on tofu quality. Food Research International, 39(3), 309-317. http://dx.doi.org/10.1016/j.foodres.2005.08.003.

Rocha, M. S., Figueiredo, R. W. D. E., Antônio, M., Mota, D. A., Saraiva, R., \& Reis, D. O. S. (2013). Caracterização físico-química e atividade antioxidante in vitro de frutos do Cerrado Piauiense. Revista Brasileira de Fruticultura. 35(4), 933-941. https://doi.org/10.1590/ S0100-29452013000400003.

Rocha-Olivieri, C. M., Conti-Silva, A. C., \& Lopes-Filho, J. F. (2012). Avaliação das características físico-químicas e microbiológicas dos componentes fibrosos obtidos da moagem úmida de grãos de milho Physical-chemical and microbiological characteristics of fibrous components obtained from corn wet milling. Revista do Instituto Adolfo Lutz, 71(4), 728-732.

Shevchenko, A., Tomas, H., Havli, J., Olsen, J. V., \& Mann, M. (2007). In-gel digestion for mass spectrometric characterization of proteins and proteomes. Nature Protocols, 1(6), 2856-2860. http://dx.doi. org/10.1038/nprot.2006.468. PMid:17406544.

Shewry, P. R., Napier, J. A., Tatham, A. S., Shewry, P. R., Napier, J. A., \& Ashton, L. (2015). Seed Storage Proteins: Structures and Biosynthesi. American Society of Plant Physiologist, 7(7), 945-956.

Silva, A. G. M., \& Fernandes, K. F. (2011). Composição química e antinutrientes presentes nas amêndoas cruas e torradas de chicha (Sterculia striata A. St. Hill \& Naudin). Revista de Nutrição, 24(2), 305-314. https://doi.org/10.1590/S1415-52732011000200011.

Sniffen, C. J., O'Connor, J. D., Van Soest, P. J., Fox, D. G., \& Russell, J. B. (1992). A net carbohydrate and protein system for evaluating cattle diets : 11. Carbohydrate and protein availability. Journal of Animal Science, 70(11), 3578-3596. http://dx.doi.org/10.2527/1992.70113562x. PMid:1459919.

Stefanes, M., Roque, F. O., Lourival, R., Melo, I., Renaud, P. C., \& Quintero, J. M. O. (2018). Property size drives differences in forest code compliance in the Brazilian Cerrado. Land Use Policy, 75, 4349. https://doi.org/10.1016/j.landusepol.2018.03.022.

Universidade Estadual de Campinas - UNICAMP. (2011). Tabela Brasileira de Composição de Alimentos - TACO (versão 4). Campinas: UNICAMP/NEPA.

Zarkadas, C. G., Gagnon, C., Gleddie, S., Khanizadeh, S., Cober, E. R., \& Guillemette, R. J. D. (2007). Assessment of the protein quality of fourteen soybean [Glycine max (L. ) Merr. ] cultivars using amino acid analysis and two-dimensional electrophoresis. Food Research International, 40(1), 129-146. http://dx.doi.org/10.1016/j. foodres.2006.08.006. 